\title{
The role of probiotics in preventing dental caries
}

\author{
Pegah Shakib*1, Samaneh Rouhi ${ }^{2}$, Mohammad Reza Zolfaghari ${ }^{3}$ \\ ${ }^{1}$ Razi Herbal Medicines Research Center, Lorestan University of Medical Sciences, Khorramabad, Iran \\ ${ }^{2}$ Medical Microbiology Research Center, Qazvin University of Medical Sciences, Qazvin, Iran \\ ${ }^{3}$ Department of Microbiology, Qom Branch, Islamic Azad University, Qom, Iran
}

\section{*Correspondence to: \\ Dr. Pegah Shakib \\ shakib.pegah@yahoo.com}

Received: 16 March 2020

Accepted: 02 April 2020

ePublished: 16 June 2020

Keywords: Oral diseases, Dental, Dental caries, Probiotics

\section{Citation:}

Shakib P, Rouhi S, Zolfaghari MR. The role of probiotics in preventing dental caries. Plant Biotechnology Persa. 2020; 2(1): 55-58.

\section{Abstract}

Tooth decay has occurred due to the numerous microorganisms in the mouth such as Streptococcus and Lactobacilli bacteria that can produce acid. Commercial antiplatelet agents are predominantly antibacterial compounds, but these compounds can disrupt oral bacterial flora and induce and enhance the growth of opportunistic pathogens, including Candida albicans. Nowadays, bacterial therapy is a replacement therapy for microorganisms. One of the methods of bacterial therapy is the use of probiotic bacteria. So far, many studies have been done on the effect of probiotic-containing food products on the microbial factors of tooth decay. Therefore, this study aimed to investigate the effect of probiotics on dental caries. The search queries were from ISI, PubMed, Scopus, Science Direct, magiran, SID databases. Key words were probiotic, dental caries, bacterial caries, tooth decay, laboratory and clinical studies. Finally, the selected articles were used for the review table. The results of the review of studies showed that probiotic strains are able to control bacterial agents that cause dental caries.

\section{Introduction}

Caries is the most common chronic disease of childhood and adolescence with nutritional program, salivary microflora and host response contributing to it [1]. Tooth decay has occurred due to the numerous microorganisms in the mouth such as Streptococcus and Lactobacilli bacteria that can produce acid. Commercial antiplatelet agents are predominantly antibacterial compounds, but these compounds can disrupt oral bacterial flora and lead to the induction and growth of opportunistic pathogens including Candida albicans [2,3]. Important strategies for preventing caries are focused on carbohydrates and microorganisms, and the removal of caries-related microorganisms from the oral environment seems not only harsh but also unreasonable, hence alternative ways to effect environmental ecology have been studied [4-6]. Dental caries are a major part of clinical problems. Bacterial therapy is a replacement therapy for microorganisms. One of the methods of bacterial therapy is the use of probiotic bacteria. The World Health Organization (WHO) describes probiotics as living microorganisms that "provide the host with health benefits if consumed to the extent necessary. This definition emphasizes the importance of probiotics as living cells. Probiotic organisms alter conditions in favor of beneficial bacteria in the gut. These microorganisms are essential for the digestion of nutrients and the balance of the intestinal microflora. So far, many researches have been done on the effect of probiotic-containing food products on the microbial agents of tooth decay. In this study, we tried to investigate the clinical and in vitro effects of probiotics on tooth decay.

\section{Methodology}

The search queries were from ISI, PubMed, Scopus, Science Direct, Magiaran, SID databases. Key words were probiotic, dental caries, bacterial caries, laboratory and clinical studies. Finally, the selected articles were used for the review table.

Copyright (C) 2020 The Author(s). This is an open-access article distributed under the terms of the Creative Commons Attribution License (http://creativecommons.org/licenses/by/4.0), which permits unrestricted use, distribution, and reproduction in any medium, provided the original work is properly cited. 


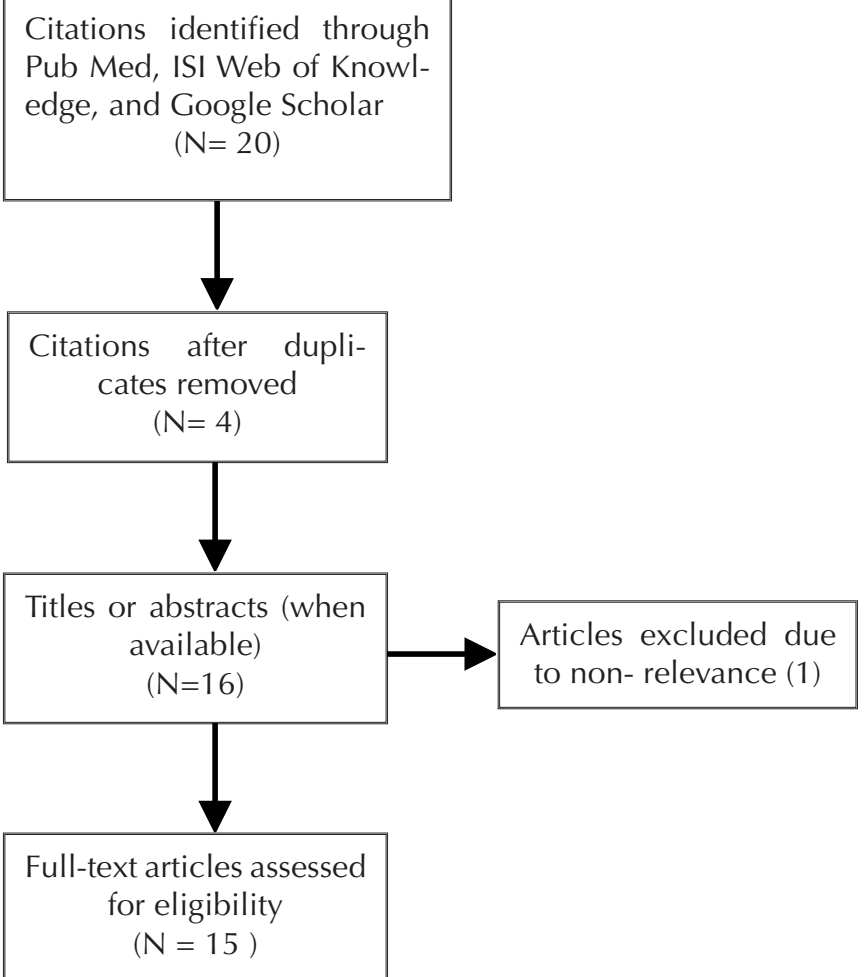

Figure1. Flow diagram for study selection

\section{Results}

The results of the study by Busscher et al. (1999) showed that probiotics of L. Acidophilus and L. rhamnosus GG, L. casei have a positive relationship with Streptococcus mutans inhibition [7]. The results of the study by Haukioja et al (2009) showed that probiotics L. paracasei, L. rhamnosus L. johnsonii by binding and survival in saliva bind to lactobacillus better than bifidobacterium [8]. The results of the study by Lima et al. (2005) showed that probiotics of L. casei Shirota and L. acidophilus have different pattern of binding to the tested species [9]. The results of the study by Hasslof et al. (2010) showed that probiotic Lactobacilli species (L. plantarum, L. paracases, L. rhamnosus GG and L. acidophilus La5, L. reuteri) by inhibiting Streptococcus mutans inhibition Different capacities in Streptococcus mutans inhibition are examined depending on the species studied [10]. The results of the study by Haukioja et al. (2008) showed that probiotics of L. casei Shirota, L. rhamnosus GG, Bifidobacterium lactis, L. reuteri Bb12 by inhibiting the protein composition of saliva polyclonal and binding of other oral bacteria inhibited the binding of other bacteria and Improvement of the protein composition of the saliva polycrystalline [11]. The results of Pham et al.s (2009) study showed that probiotic L. salivarius W24 has a stabilizing effect on the salivary microflora, affecting the composition stability and decay of salivary bacteria, stabilizing the salivary microflora, altering the composition and decay of salivary bacteria [12]. The results of the study by Comelli et al. (2002) showed that probiotic Lactococcus lactis and S. thermophilus are inhibited by different inhibitory effects on the growth inhibition of Streptococcus mutans [13]. The results of Nase et al's (2001) study showed that probiotic L. rhamnosus GG reduces salivary Streptococcus mutans [14]. The results of Nikawa et al.s (2004) study showed that probiotic L. reuteri causes salivary
Streptococcus mutans [15]. The results of Caglar et al's (2005) study showed that Bifidobacterium probiotic reduces salivary Streptococcus mutans [16]. The results of Caglar et al's (2006) study showed that probiotic ihd and L.reuteri L.reuteri decrease Streptococcus mutans salivation [17]. The results of Montalto et al.s (2004) study showed that Lactobacillus spp probiotic increases lactobacillus and does not alter salivary Streptococcus mutans [18]. The results of the study by Cildir et al (2009) showed that the probiotic Bifidobacterium animalis subsp. Lactis DN-173010 reduces Streptococcus mutans and does not alter lactobacilli in saliva [19]. The results of the study by Steeksen et al. (2009) showed that probiotic L. rhamnosus LB21 reduces Streptococcus mutans [20]. The results of the study by Chuang et al. (2010) showed that probiotic L. paracasei GMNL-33 did not change Streptococcus mutans in saliva immediately after the intervention and decreased 2 weeks after the end of the intervention [21]. The results of Caglar et al.s (2008) study showed that the probiotic Bifidobacterium lactis Bb- 12 reduced Streptococcus mutans and did not alter lactobacilli in saliva [22]. The results of Caglar et al.s (2006) study showed that probiotics L.reuteri and L.reuteri reduce Streptococcus mutans in saliva [17].

Table1. Summary of studies involved in the meta-analysis.

\begin{tabular}{clcc}
\hline $\begin{array}{l}\text { Refer- } \\
\text { ence }\end{array}$ & $\begin{array}{l}\text { probiotics in pre- } \\
\text { venting dental caries }\end{array}$ & $\begin{array}{c}\text { Publication } \\
\text { year }\end{array}$ & First author \\
\hline [7] $\quad \begin{array}{l}\text { L. acidophilus } \boldsymbol{Q} \text { L. } \\
\text { rhamnosus GG , L. }\end{array}$ & 1999 & $\begin{array}{c}\text { Busscher et } \\
\text { al. }\end{array}$
\end{tabular}

L. paracasei $\otimes \mathrm{L}$.

[8] rhamnosus L. johnsonii

2009

Haukioja et al.,

[9] casei Shirota, L. acidophilus

2005

Lima et al.,

Lactobacilli L. para-

[10] cases खL. rhamnosus GG

2010 Hasslof et al.

L. casei Shirota, L.

[11] fidobacterium lactis

2008 Haukioja et , L. reuteri Bb12

[12] L. salivarius W24

Pham et al

[13] Lactococcus lactis , S. thermophilus

Comelli et al

[14] L. rhamnosus GG

2001

Nase et al

[15] L. reuteri

2004

Nikawa et al

[16] Bifidobacillus

2005

[17] L.reuteri L.reuteri

2006

[18] Lactobacillus spp

Caglar et al

Caglar et al

Montalto et al

Bifidobacterium an-

[19] imalis subsp. Lactis DN-173010

$2009 \quad$ Cildir et al

[20] L. rhamnosus LB21

2009

Steeksen et al 


\begin{tabular}{clcl}
\hline $\begin{array}{l}\text { Refer- } \\
\text { ence }\end{array}$ & $\begin{array}{l}\text { probiotics in pre- } \\
\text { venting dental caries }\end{array}$ & $\begin{array}{c}\text { Publication } \\
\text { year }\end{array}$ & First author \\
\hline$[21]$ & $\begin{array}{l}\text { L. paracasei GMNL- } \\
33\end{array}$ & 2010 & Chuang et al \\
& $\begin{array}{l}\text { Bifidobacterium } \\
\text { lactis Bb-12 }\end{array}$ & 2008 & Caglar et al
\end{tabular}

\section{Discussion}

Probiotics work by various mechanisms in the oral cavity, including the production of antibacterial agents against oral pathogens such as hydrogen peroxide organic acids and bacteriocins [23-27]. In another mechanism, probiotics compete with pathogenic agents for adhesion to the mucosa and teeth and prevent the attachment and invasion of pathogenic bacteria $[28,29]$. The next mechanism of probiotics is that they can alter the environment of the oral environment, such as a severe decrease in $\mathrm{pH}$ so that caries are not able to survive in the highly acidic environment, or a change in the protein structure of the salivary polyacrylate and a decrease in agglutinin GP340 and Saliva peroxidase [30]. Finally, probiotics can have beneficial effects by stimulating nonspecific immunity and regulating cellular and humoral immune responses [31,32], but further studies on the sites of induction and immunity in the mouth after the administration of probiotics are needed. Often a combination of probiotic strains is used to enhance these beneficial effects [33]. Harmless bacteria in fermented food products compete with the pathogenic bacteria after consumption and impede their viability. Probiotic bacteria work in several ways: prevent cell adhesion and invasion of pathogenic bacteria, compete with pathogenic bacteria to provide the required materials and adhere to the environment, may kill toxins or produce antimicrobial substances. They are also effective in regulating local and systemic immune systems [34, 35]. Evidence from studies has shown that different probiotic strains can prevent dental caries by controlling bacterial caries.

\section{Acknowledgments}

The authors would like to thank the Vice-chancellor for the Research and Technology Deputy of the Lorestan University of Medical Sciences, Khorramabad, Iran for funding this study.

\section{Authors' contributions}

PSH and SR searched and reviewed the literature and PSH and MRZ prepared the first draft of manuscript; SR and PSH helped in preparing final draft of manuscript, checked and corrected the grammar. All authors read and approved the final report.

\section{Conflict of interests}

All authors declare that no conflict of interest exist.

\section{Funding/Support}

None.

\section{References}

1. Braunwald E, Fanci AS, Kasper DL, et al. Harrison's Principles of Internal Medicine. 15th ed. Newyork: Mc Graw-Hill; 2001: 1620.

2. Mandell GL, Bennettes JE, Dolin R. Practice of Infectious Diseases. 5th ed. Philadelphia: Churchill Livingstone; 2000:
780.

3. Eschenbach DA. Pelvic and sexually transmitted infections. In: Gibbs RS, Karlan BY, Haney AF, Nygaard IE. Danforth's obstetrics and gynecology. 10th ed. Philadelphia:Lippincott Williams \& Wilkins; 2008: 604-21.

4. Anderson MR, Klink K, Cohrssen A. Evaluation of vaginal complaints. JAMA 2004; 17; 291(11):1368-79.

5. Wiesenfeld HC, Hillier SL, Krohn MA, Landers DV, Sweet RL. Bacterial vaginosis is a strong predictor of Neisseria gonorrhoeae and Chlamydia trachomatis infection. Clin Infect Dis. 2003; 1 ; 36(5):663-8.

6. Watts DH, Fazzari M, Minkoff H, Hillier SL, Sha B, Glesby $M$, et al. Effects of bacterial vaginosis and other genital infections on the natural history of human papillomavirus infection in HIV-1-infected and high-risk HIV- 1-uninfected women. J Infect Dis. 2005; 1; 191(7):1129-39.

7. Brotman RM, Klebanoff MA, Nansel TR, Yu KF, Andrews WW, Zhang J, et al. Bacterial vaginosis assessed by gram stain and diminished colonization resistance to incident gonococcal, chlamydial, and trichomonal genital infection. J Infect Dis. 2010; 15; 202(12):1907-15.

8. Allsworth JE, Lewis VA, Peipert JF. Viral sexually transmitted infections and bacterial vaginosis: 2001-2004 National Health and Nutrition Examination Survey data. Sex Transm Dis. 2008; 35(9):791-6.

9. Harmanli OH, Cheng GY, Nyirjesy P, Chatwani A, Gaughan JP. Urinary tract infections in women with bacterial vaginosis. Obstet Gynecol. 2000; 95(5):710-2.

10. French L, Horton J, Matousek M. Abnormal vaginal discharge: using office diagnostic testing more effectively. J Fam Pract. 2004; 53(10):805-14.

11. Culhane JF, Desanto D, Goldenberg RL, McCollum KF, King F, Guaschino S. Variation in Nugent score and leukocyte count in fluid collected from different vaginal sites. Obstet Gynecol. 2005; 105(1):120-3.

12. Reid G, Beuerman D, Heinemann C, Bruce AW. Probiotic Lactobacillus dose required to restore and maintain a normal vaginal flora. FEMS Immunol Med Microbiol. 2001; 32:37-41.

13. Wolvers D, Antoine JM, Myllyluoma E, Schrezenmeir J, Szajewska H, Rijkers GT. Guidance for substantiating the evidence for beneficial effects of probiotics: prevention and management of infections by probiotics. J Nutrition. 2010; 140(3):698-712.

14. Soper DE. Gentiourinary infectious and sexually transmitted diseases. In: Berek JS. Berek \& Novak's gynecology. 15th ed. Philadelphia:Lippincott Williams \& Wilkins;2012:557-73.

15. Ferris DG, Litaker MS, Woodward L, Mathis D, Hendrich J. Treatment of bacterial vaginosis: a comparison of oral metronidazole, metronidazole vaginal gel, and clindamycin vaginal cream. J Fam Pract. 1995; 41(5): 443-9.

16. Brandt M, Abels C, May T, Lohmann K, Schmidts-Winkler I, Hoyme UB. Intravaginally applied metronidazolenis as effective as orally applied in the treatment of bacterial vaginosis, but exhibits significantly less side effects. Eur J Obstet Gynecol Reprod Biol. 2008; 141(2):158-62.

17. Bradshaw CS, Morton AN, Hocking J, Garland SM, Morris MB, Moss LM, et al. High recurrence rates of bacterial vaginosis over the course of 12 months after oral metronidazole therapy and factors associated with recurrence. J Infect Dis 2006; 1 ; 193(11):1478-86.

18. Kurohara ML, Kwong FK, Lebherz TB, Klaustermeyer WB. Metronidazole hypersensitivity and oral desensitization. J Allergy Clin Immunol. 1991; 88(2):279-80.

19. Bannatyne RM, Smith AM. Recurrent bacterial vaginosis 
and metronidazole resistance in Gardnerella vaginalis. Sex Transm Infect. 1998; 74(6):455-6.

20. Parent D, Bossens M, Bayot D, Kirkpatrick C, Graf F. Therapy of Bacterial Vaginosis using exogeneously-applied Lactobacilli aciophili and a low dose of estriol: A placebo-controlled multicentric clinical trial. Arzneimitell-Forschung 1996; 46: 68-73.

21. Mastromarino P, Macchia S, Meggiorini L, Trinchieri V, Mosca L, Perluigi M, et al. Effectiveness of Lactobacillus-containing vaginal tablets in the treatment of symptomatic bacterial vaginosis. Clin Microbiol Infect. 2009; 15(1): 67-74.

22. Ozkinay E, Terek MC, Yayci M, Kaiser R, Grob P, Tuncay G. The effectiveness of live lactobacilli in combination with low dose oestriol (Gynoflor) to restore the vaginal flora after treatment of vaginal infections. British J Obstetrics Gynaecol. 2005; 112(2):234-40.

23. Reid G, McGroarty JA, Angotti R, Cook RL. Lactobacillus inhibitor production against Escherichia coli and coaggregation ability with uropathogens. Can J Microbiol. 1988; 34(3): 344-51.

24. Boris S, Suarez JE, Barbes C. Characterization of the aggregation promoting factor from Lactobacillus gasseri, a vaginal isolate. J Appl Microbiol. 1997; 83(4): 413-20.

25. Kim YH, Kim CH, Cho MK, Na JH, Song TB, Oh JS. Hydrogen peroxide-producing Lactobacilli in the vaginal flora of pregnant women with preterm labor with intact membranes. Int J Gynaecol Obstet. 2006; 93(1): 22-7.

26. Ishihara K, Miyakawa H, Hasegawa A, Takazoe I, Kawai Y. Growth inhibition of Streptococcus mutans by cellular extracts of human intestinal lactic acid bacteria. Infect Immun. 1985; 49(3): 692-4.

27. Reid G, Jass J, Sebulsky MT, McCormick JK. Potential uses of probiotics in clinical practice. Clin Microbiol Rev. 2003; 16(4): 658-72.

28. Comelli EM, Guggenheim B, Stingele F, Neeser JR. Selection of dairy bacterial strains as probiotics for oral health. Eur J Oral Sci. 2002; 110(3): 218-24.

29. Riccia DN, Bizzini F, Perilli MG, Polimeni A, Trinchieri V, Amicosante G, et al. Anti-inflammatory effects of Lactobacillus brevis (CD2) on periodontal disease. Oral Dis. 2007; 13(4): 376-85.

30. Haukioja A, Loimaranta V, Tenovuo J. Probiotic bacteria affect the composition of salivary pellicle and streptococcal adhesion in vitro. Oral Microbiol Immunol. 2008; 23(4): 336-43.

31. Erickson KL, Hubbard NE. Probiotic immunomodulation in health and disease. J Nutr. 2000; 130(2S Suppl): 403S-409S.

32. Isolauri E, Sutas Y, Kankaanpaa P, Arvilommi H, Salminen S. Probiotics: effects on immunity. Am J Clin Nutr. 2001; 73(2 Suppl): 444S-450S.

33. Sanders ME. Probiotics: Definition, sources, selection, and uses. Clin Infect Dis. 2008; 46 Suppl 2: S58-S61.

34. Fitzgerald RJ, Keyes PH. Demonstration of the etiologic role of streptococci in experimental caries in the hamster. J Amer Dent Assoc. 1960; 61:9-19.

35. Caglar E, Kavaloglu SC, Kuscu OO, Sandalli N, Holgerson $\mathrm{PL}$, Twetman S. Effect of chewing gums containing xylitol or probiotic bacteria on salivary mutans streptococci and lactobacilli. Clin Oral Invest. 2007; 11:425-429. 